\title{
Teologia moral contemporânea: Status Questionis, ética e hermenêutica em 1 Jo 2,15-17
}

Orientadora: Maria Clara Lucchetti Bingemer

Mestranda: Marta Luzie de Oliveira Frecheiras

Área de Concentração: Teologia Sistemático-Pastoral

Linha de Pesquisa: Religião e Modernidade

Projeto de Pesquisa: A experiência do divino nas religiões do Livro

"Teologia moral contemporânea: Status questionis, ética e hermenêutica em 1Jo 2,15-17" propõe uma reflexão acerca das questões morais que assolam a humanidade, de Sócrates aos seres humanos contemporâneos. Faz um estudo filosófico do campo que alguns nomeiam ética e outros, moral para propor uma reflexão acerca da teologia moral e/ou da ética religiosa. Essa dissertação inicia pelo estado da questão, para perceber o fundamento filosófico presente em toda teologia moral. Realiza uma síntese da ética filosófica, destacando seus horizontes e as principais correntes éticas contemporâneas. Apresenta uma fundamentação histórica da teologia moral, do horizonte tridentino ao contexto pós-Vaticano II, procurando demonstrar que ela sempre esteve a reboque dos acontecimentos, e não diante deles, acenando por qual caminho o cristão pode e deve enveredar-se. Na sequência, faz uma tentativa de refletir acerca do possível substrato bíblico da teologia moral, expondo os pontos essenciais do documento da Pontifícia Comissão Bíblica denominado "Bíblia e Moral". Por fim, traça rotas de investigação para a compreensão da moral nos livros bíblicos, detendo-se nas Cartas Católicas - aspectos principais da primeira Epístola de João - e realiza uma análise particular da ética na hermenêutica de 1Jo 2,15-17, a fim de poder demonstrar que o papel da teologia moral católica na contemporaneidade é o de "humanizar" o ser humano, reafirmando que não há outro modelo a ser seguido a não ser Jesus Cristo.

Palavras-chave: Ética e moral. Bíblia e moral. Ética religiosa. 